\title{
Honey physicochemical properties of three species of the brazilian Melipona
}

\section{LORENA G.A. LAGE, LÍVIA L. COELHO, HELDER C. RESENDE, MARA G. TAVARES, LUCIO A.O. CAMPOS and TÂNIA M. FERNANDES-SALOMÃO}

Departamento de Biologia Geral, Universidade Federal de Viçosa, Avenida PH Rolfs, s/n, 36570-000 Viçosa, MG, Brasil

Manuscript received on April 19, 2010; accepted for publication on December 16, 2011

\begin{abstract}
Physicochemical analyses were carried out to evaluate 27 samples of honeys from three species of the Brazilian genus Melipona (M. capixaba, M. rufiventris and M. mondury) from Espírito Santo and Minas Gerais States. The parameters water activity (Aw), percentage of soluble solids (Brix \%), pH, acidity (meq/Kg) and moisture (\%) were evaluated. The honey characteristics obtained from these samples were very similar to the ones from other Melipona species. However, regarding the honey from Apis (honey bee), only the $\mathrm{pH}$ values were similar. The low $\mathrm{pH}$ value and the high acidity detected in Melipona honey are potential factors for increasing the honey shelf life because they do not provide favorable conditions for the microbial development. On the other hand, the high level of water activity favors the growth of microorganisms, especially yeast, which demands a more careful handled and storage. The observed differences between Melipona and Apis honey reinforce the need for specific quality settings for stingless bee honey.
\end{abstract}

Key words: Honey, Melipona, Meliponini, Physicochemical data.

\section{INTRODUCTION}

This work shown differences in values of water activity, Brix, $\mathrm{pH}$, acidity and moisture between Melipona and Apis honey and reinforce the need for specific quality settings for stingless bee honey.

The Brazilian social bees, sub-tribe Meliponini, are considered the main pollinator agents of the Brazilian trees (Kerr et al. 1996). There are more than 200 different Meliponini species, including the stingless bee, and some of them are frequently raised for honey production.

The honey physicochemical characteristics of these bees are not very well known, mainly in the

Correspondence to: Tânia Maria Fernandes Salomão

E-mail: fernands@ufv.br tropical regions where there is a great flora diversity associated to high temperature and moisture. It is estimated that honey comes from more than 2.500 types of flowers from different plants; therefore their characteristics vary widely. Honey composition depends on several factors, such as nectar composition, source location, harvesting, season, management and especially bee species (Carvalho et al. 2006).

The aim of this work was to study the honeys of three species of the genus Melipona through physicochemical analyses. Honey from M. capixaba $(n=9)$ was collected in May 2008 from hives in the Atlantic Forest at the cities of Alfredo Chaves, Domingos Martins and Venda Nova do Imigrante (Espírito Santo State). Honey from M. rufiventris 
$(n=7)$ was collected from April 2003 to May 2004 in the Brazilian savannah at the cities of Guimarânia, Patrocinio, Brasilandia de Minas and Dom Bosco. Honey from $M$. mondury $(\mathrm{n}=11)$ was collected during the same months interval in the Atlantic Forest at the cities of Rio Vermelho and Diogo de Vasconcelos (Minas Gerais State). All samples were analyzed immediately after the collection.
The parameters water activity (Aw), percentage of soluble solids (Brix \%), pH, acidity (meq/Kg) and moisture $(\%)$ were analyzed. The analyses were carried out following the Analitical Standards from Instituto Adolfo Lutz - Métodos Físico-Químicos para Análise de Alimentos (Instituto Adolfo Lutz 2005). Table I shows the physicochemical data of the studied honeys.

TABLE I

Physicochemical analysis of three Melipona species. The values are standard error of averages. Minimum and maximum values are in brackets.

\begin{tabular}{|c|c|c|c|c|c|c|c|}
\hline \multirow[b]{2}{*}{ Species/ Bioma } & \multirow{2}{*}{$\begin{array}{l}\text { Water } \\
\text { activity } \\
(\mathrm{Aw})\end{array}$} & \multirow[b]{2}{*}{ Moisture (\%) } & \multirow[b]{2}{*}{$\mathrm{pH}$} & \multirow{2}{*}{$\begin{array}{c}\text { Soluble } \\
\text { solids (\%) }\end{array}$} & \multicolumn{3}{|c|}{ Acidity } \\
\hline & & & & & $\begin{array}{c}\text { Free } \\
(\mathrm{meq} / \mathrm{Kg})\end{array}$ & $\begin{array}{l}\text { Lactonic } \\
(\mathrm{meq} / \mathrm{Kg})\end{array}$ & $\begin{array}{c}\text { Total } \\
\text { (meq/Kg) }\end{array}$ \\
\hline \multicolumn{8}{|l|}{ Melipona capixaba } \\
\hline \multicolumn{8}{|l|}{ (Atlantic forest $)(n=9)$} \\
\hline Range & $(0.69-0.77)$ & $(25.84-36.04)$ & $(3.30-3.80)$ & $(62.20-72.8)$ & $(25.0-107.0)$ & $(7.0-17.50)$ & $(34.0-118.50)$ \\
\hline Mean \pm standard error & $0.73 \pm 0.03$ & $30.51 \pm 3.55$ & $3.62 \pm 0.15$ & $68.23 \pm 3.55$ & $67.94 \pm 33.20$ & $11.33 \pm 3.24$ & $79.28 \pm 33.37$ \\
\hline \multicolumn{8}{|l|}{ Melipona rufiventris } \\
\hline \multicolumn{8}{|l|}{ (Brasilian savannah) $(\mathrm{n}=7)$} \\
\hline Range & $(0.59-0.65)$ & - & $(4.05-4.50)$ & $(7.0-77.0)$ & $(1.0-52.0)$ & $(10.0-17.0)$ & $(3.5-69.0)$ \\
\hline Mean \pm standard error & $0.62 \pm 0.02$ & - & $4.24 \pm 0.19$ & $74.12 \pm 1.86$ & $2.43 \pm 10.74$ & $1.57 \pm 2.30$ & $42.0 \pm 12.31$ \\
\hline \multicolumn{8}{|l|}{ Melipona mondury } \\
\hline \multicolumn{8}{|l|}{$($ Atlantic forest $)(n=11)$} \\
\hline Range & $(0.69-0.79)$ & & $(3.17-5.67)$ & $(63.0-71.0)$ & $(2.07-122.50)$ & $(1-15.38)$ & $(30.5-132.50)$ \\
\hline Mean \pm standard error & $0.74 \pm 0.03$ & - & $4.19 \pm 0.81$ & $68.09 \pm 2.84$ & $52.77 \pm 31.93$ & $8.73 \pm 4.50$ & $61.51 \pm 33.2$ \\
\hline $\begin{array}{c}\text { Maximum accepted } \\
\text { Brasil } 2000\end{array}$ & & $\begin{array}{c}\text { not more than } \\
20 \%\end{array}$ & $3.3-4.6$ & & & & $\begin{array}{c}\text { not more than } \\
50 \mathrm{meq} / \mathrm{Kg}\end{array}$ \\
\hline
\end{tabular}

The water content is one of the main differences between honey from stingless bees and Apis. In general, it has been showed that the water activity values of honey from Apis (honey bee) ranged from 0.49 to $0.60 \mathrm{aW}$ (Alcalá and Gómez 1990). This represents a non-satisfactory condition for the activity of several microorganisms that depend on a higher amount of free water for growth and survival. However, most honey showed water activity values ( 0.59 to $0.79 \mathrm{aW}$ - Table I) higher than those from honey bees. The moisture content of honey is highly important for its shelf life (Pérez-Arquillué et al.
1994). In general, high moisture content causes honey fermentation, spoiling and flavor loosing, leading its loss of quality (Costa et al. 1999).

The moisture levels of M. capixaba honey (25.84 to $36.04 \%$ - Table I) exceeded the limits specified by the National and International legislations $(20 \%)$. High moisture values have also been reported for honey from other Melipona species: $26.80 \%$ to $32.00 \%$ for M. asilvai (Souza et al. 2004), $23.14 \%$ to $32.50 \%$ for M. mandacaia, (Alves et al. 2005), 24.8\% to $30.6 \%$ for the Amazon Melipona (M. compressipes manaoense and M. seminigra merribae) (Almeida- 
Muradian et al. 2007) and recently, for M. scutellaris (Ilha de Itaparica, Bahia State), and 25\% and $>30 \%$ for M. quadrifasciata (Costa do Sauípe, Bahia state) (Carvalho et al. 2009). This feature deserves care in handling. On the other hand, the high moisture content is directly related to the flavor of the product that is much appreciated because it is less sweet and nauseating.

The honey of these three Melipona species showed a content of soluble solids ranging from $62.2 \%$ to $77.0 \%$ (Table I). This result corroborated Souza et al. (2006) who studied the honeys from M. compressipes triplaridis (67.0 to $75.5 \%), M$. fuliginosa (68.0 to $75.0 \%$ ) and M. panamica (57.2 to $75.0 \%$ ). However, the brix value from Apis honey is higher (example, 78.8 to $84 \%$; Terrab et al. 2004). Moreover, according to Anupama et al. (2003), there was a high negative correlation between brix \% and moisture content in Apis honey. So, the lower content of soluble solids from Melipona honey may be related to their higher moisture content.

The $\mathrm{pH}$ values of Melipona honey ranged from 3.17 to 5.67 (Table I). This pHvariation was previously reported by Almeida-Muradian et al. (2007) in the Amazon Melipona (mean value of $\mathrm{pH} 3.41$ ), for M. scutellaris and in M. quadrifasciata honey, both from Ilha de Itaparica (mean values of $\mathrm{pH} 3.71$ and 3.67, respectively) and from Costa do Sauípe (means values of pH 6.64 and 3.74, respectively) (Carvalho et al. 2009). These values are comparable to those reported for Apis honey from different countries. For example, it was 3.5 for the Italian honey (Esti et al. 1997), 4.2, 3.99 and 4.02 for the Spain honey (Terrab et al. 2004, Lópes et al. 1996).

The total acidic is the sum of free and lactonic acidities, and the maximum value accepted by the Brazilian legislation is $50 \mathrm{meq} / \mathrm{Kg}$ (Brasil 2000). Regarding Melipona honey, the total acidic values ranged from 30.5 to $132.5 \mathrm{meq} / \mathrm{Kg}$ (Table I) and this honey acidity is higher than the maximum recommended (Brasil 2000). It seems that high acidity is common for Melipona honey. For example, Vit et al. (1994) also reported elevated acidic values for $M$. compressipes (33.93 - 94.12) and M. favosa (18.63 -228.80) honey. On the other hand, M. trinitati honey presented acidity values ranging from 12.92 to 35.30 (Vit et al. 1994), M. scutellaris and M. quadrifasciata honey from Ilha de Itaparica presented acidity mean values of 25.75 and 55.0 and from Costa do Sauípe had acidity mean values ranging from 6.25 and 28.0 (Carvalho et al. 2009). Almeida-Muradian et al. (2007) also reported for the Amazon Melipona acidic values below $50 \mathrm{meq} / \mathrm{Kg}$ (20.63 to 27.82). These last ones matched the reported data for Apis honeys from different geographical locations (e.g. Lópes et al. 1996, Esti et al. 1997, Terrab et al. 2004, Downey et al. 2005). As mentioned above, Melipona honey can present high levels of total acidic. Although high acidic is a feature that makes the honey attractive to consumers, it can indicates the state of honey maturity rising with fermentation.

The variations found in honey from Melipona species might be due to different honey sources, since the honey samples came from different biomas and sites. According to Carvalho et al. (2006), honey composition may vary depending on the flora, location, harvest season, management and especially the bee species that produced the honey. The low $\mathrm{pH}$ value and the high acidity represent a potential increasing of the honey shelf life because these conditions do not favor the microbial growing. On the other hand, it can be inferred that the high acidic values indicated the presence of undesirable fermentation, especially if honey presents higher contents of water activity and moisture. This might favor the microbial growing, specially yeasts, which suggests that this kind of honey needs to be handled and stored carefully to avoid microbiologic contamination. The observed differences between Melipona and Apis honey reinforce the need for specific quality settings for stingless bee honey. Moreover, further research is need for the establishment of quality patterns for the management of honey from native bees. 


\section{ACKNOWLEDGMENTS}

We thank Dra. R.C.S. Mendonça for helping with the analyses of samples. We are grateful to the beekeepers F. Calimã, J. Valim and J.R. Carvalho for providing natural honey samples. We gratefully acknowledge the support of this research by Fundação de Amparo à Pesquisa do Estado de Minas Gerais (FAPEMIG).

\section{RESUMO}

Análises fisico-quimicas foram realizadas para avaliar vinte e sete amostras de mel de três espécies do gênero Melipona (M. capixaba, M. rufiventris e M. mondury) coletadas nos Estados do Espírito Santo e de Minas Gerais. Os parâmetros atividade de água $(\mathrm{aW})$, porcentagem de sólidos solúveis (Brix \%), $\mathrm{pH}$, acidez (meq. $\mathrm{Kg}^{-1}$ ) e umidade (\%) foram avaliados. As características do mel dessas amostras foram muito similares às do mel de outras espécies de Melipona. Entretanto, para o mel de Apis apenas os valores de $\mathrm{pH}$ foram similares. $\mathrm{O}$ baixo valor de $\mathrm{pH}$ e a elevada acidez detectados no mel de Melipona são fatores potenciais para uma maior vida útil do mesmo por não oferecerem condições favoráveis ao desenvolvimento microbiano. Por outro lado, o alto teor de atividade de água favorece o crescimento de microrganismos, especialmente de leveduras o que requer maior cuidado no manuseio e armazenamento do mel. As diferenças observadas entre o mel de Melipona e o de Apis reforçam a necessidade de estabelecimento de padrões de qualidade específicos para o mel de abelhas sem ferrão.

Palavras-chave: Mel, Melipona, Meliponini, Dados físico-químicos.

\section{REFERENCES}

AlCAlÁ M AND GÓMEZ R. 1990. Cálculo de la actividad de agua de la miel. Aliment Equip y Tecnol Mayo, p. 99-100.

AlMEIDA-Muradian LB, MATSUdA AH AND BAstos DHM. 2007. Physicochemical parameters of amazon Melipona honey. Quim Nova 30: 707-708.

Alves RMO, Carvalho CAL, Souza BA, Sodré GS AND MARCHINI LC. 2005. Características físico-químicas de amostras de mel de Melipona mandacaia Smith (Hymenoptera: Apidae). Cienc Tecnol Aliment 25: 644-650.
ANUPAMA D, BhAT KK AND SAPNA VK. 2003. Sensory and physic-chemical properties of commercial samples of honey. Food Res Internat 36: 183-191.

BRASIL. 2000. Ministério da Agricultura, Pecuária e Abastecimento. Legislação de Produtos Apícolas e Derivados. Instrução Normativa 11, de 20 de outubro de 2000, Regulamento técnico de identidade e qualidade do mel. Diisponível em: http://www.agricultura.gov.br/sda/dipoa/ in_11_2000.htm.

INSTITUTO ADOLFO LUTZ. 2005. Métodos físico-químicos para análise de alimentos: normas analíticas do Instituto Adolfo Lutz, $4^{\mathrm{a}}$ ed., Brasília (DF): ANVISA.

CARVAlHo CAL, Sodré GS, FonseCA AAO, Alves RMO AND SOUZA ACL. 2009. Physicochemical characteristics and sensory profile of honey samples from stingless bees (Apidae: Meliponinae) submitted to a dehumidification process. An Acad Bras Cienc 81: 143-149.

Carvalho CAL, Sodré GS, Fonseca AaO, Silva SMPC, OliveIRA GA AND Clarton L. 2006. Perfil sensorial de amostras de méis de espécies de abelhas sem ferrão do Estado da Bahia. Magistra 18: 265-269.

Costa L, Albuquerque M, Trugo L, Quinteiro L, Barth O, Ribeiro M AND De MARIA C. 1999. Determination of non-volatile compounds of different botanical origin Brazilian honeys. Food Chem 65: 347-352.

Downey G, Hussey K, Kell JD, WALshe TF and Martin PG. 2005. Preliminary contribution to the characterization of artisanal honey produced on the Ireland by palynological and physico-chemical data. Food Chem 91: 347-354.

Esti M, PANFILI G, MARCONI E AND TRIVISONNO MC. 1997. Valorization of the honeys from the Molise region through physico-chemical, organoleptic and nutricional assessment. Food Chem 58: 125-128.

KerR WE, CARVALHO GA AND NASCIMENTO VM. 1996. Abelha Urucu. Biologia, Manejo e Conservação. Coleção Manejo da Vida Silvestre. Belo Horizonte. Fundação Acangaú, 143 p.

LÓpes B, LATORRE MJ, FERnANDEZ MI, GARCiA S AND HerRero C. 1996. Chemometric classification of honeys according to their type based on quality control data. Food Chem 55: 281-287.

PÉreZ-Arquillué C, CONChello P, Ariño A, JuAN T AND HERRERA A. 1994. Quality evaluation of Spanish rosemary (Rosmarinus offcinalis) honey. Food Chem 51: 207-210.

SouzA B ET AL. 2006. Composition of stingless bee honey: setting quality. Interciência 31: 867-875.

Souza BA, CARVAlHo CAL, SODRÉ GS AND MARChINI LC. 2004. Características físico-químicas de amostras de mel de Melipona asilvai (Hymenoptera: Apidae). Cienc Rural 34: 1623-1624.

Terrab A, Recamales A, Hernanz D and Heredia F. 2004 Caracterization of Spanish thyme honeys by their physicochemical characteristics and mineral contents. Food Chem 88: 537-542.

ViT P, BogdanOV S AND KILCHENMAN V. 1994. Composition of Venezuelan honeys from stingless bees (Apidae: meliponae) and Apis mellifera L. Apologie 25: 278-288. 